\title{
The History of Islamic Education of Salafi in Tanah Melayu (1820-1950)
}

\author{
Siti Marpuah ${ }^{1}$, Shakila Ahmad ${ }^{2}$ \\ Lecturer at Department of Islamic Studies, Centre for General Studies and Co-curricular, \\ Universitas Tun Hussein Onn Malaysia ${ }^{1}$ \\ Lecturer at Department of Islamic Studies, Centre for General Studies and Co-curricular, \\ Universiti Tun Hussein Onn Malaysia ${ }^{2}$ \\ \{marpuah@uthm.edu.my ${ }^{1}$, shakila@uthm.edu.my $\left.{ }^{2}\right\}$
}

\begin{abstract}
Islamic education Salafi / Pondok is the foundation of the construction of human civilization in the past. In the Muslim community in Tanah Melayu, especially in the Johor-Riau area, there are many forms of scholarship inherited from the old generation to the new generation. This includes Salafi's Islamic education which consists of the study of classical books, studies based on the manuscripts of the yellow books or jawi writing texts in the Riau district of Riau. These books will break the various Islamic disciplines such as books of Jurisprudence, Aqidah, Sufism, Shari'a, Muamalat and so on. In this period the process of Islamization of science gave birth to Islamic Malay characters, the body of Islamist movements such as the tarikat and emerging institution of pondok which gave birth to figure and ulama in Johor Riau which then spread in the archipelago and Malaya. This study will focus more on the history of Islamic education of salafi in Johor Riau especially and in Malaya in general.
\end{abstract}

Keywords: Salafi Islamic Education, Classical Books, Malay Islamic Figures

\section{Introduction}

Islam is a universal religion that comes from Allah SWT to all people. It gives light to humans in shaping civilization towards perfection based on the guidance of the divine revelation, while not setting aside the role of human reason. The light of Islam was felt by the people in the Malay world when it started to spread Islam. This effort has yielded results that can be witnessed to this day because the task of spreading Islam is entrusted to every Muslim, irrespective of race, color, posterity,and position. Hence, Muslims are all around the world and are made up of various races and colors.

The arrival of Islam has brought renewal to the life of a different Malay society with the establishment of a new Islamic-based civilization[1]. In the era of traditional Islamic education in Johor Riau, only in the reign of Raja Ali Ibni Raja Jaafar Yang Dipertuan Muda Riau 8th only emphasized on religion. He has built many Islamic education centers and invited scholars to teach in Riau. He also frequently sought advice from his cousins who were proficient in religious knowledge especially Raja Ali Haji, the son of Raja Haji Ahmad ibni Raja Haji.

That study related to Salafi Islamic education in Johor-Riau districts needs to be done because to know how the actual development of Islamic education in Johor Riau. The 
influence of Raja Ali Haji has spread throughout the archipelago especially to the Johor government which became its "twin kingdom."Thisis evidenced by the action of Temenggung Abu Bakar who sent Engku Haji and Bentara Johor to Penyengat Island to ask Raja Ali Haji's opinion whether he could use the Sultan's name or not [2]. Also, this study was also conducted to find out how Islam spread in Johor-Riau and the archipelago. The glorious era of the Johor rulers has given birth to several Islamic cultural figures and one of the most famous of which is King Ali (1809-1870M). His not only in the field of history and language but also in the form of a Malay lawmaker and trader.

Its existence in the century has brought Johor into the center of the spread of Islam in the archipelago to replace the Islamic kingdom of Acheh. The glory of the Johor-Riau government is known as the glorious era of Islamic literature in the Nusantara [3]. Therefore, the study of Salafi Islamic education is very important because the advent of Islam has instilled a positive attitude to call on Muslims to seek knowledge, especially those related to Islam[4]. Islamic education of Salafi has also spread to the area of Johor-Riau.

This study was conducted to identify the history of Islamic education of Salafi in the area of Johor Riau[5]. As we have already seen, the arrival of Islam in Malaya is remarkable in the area of Johor Riau and the archipelago has long been dispersed. The development of Islamic education[6] of Salafi or cottage education is linked with some scholars who carry out the activities of spreading Islam in the area of Johor Riau, especially covering the entire archipelago.

To find out exactly what was the beginning of the arrival of the Islamic education of Salafi or the cottage system in Johor Riau and the archipelago in ancient times, especially during colonial times, it was necessary to make a study related to it. This is because the spread of Islam took place at that time. The arrival of Islam in Johor Riau has transformed the royal system of that time which emphasized the Islamic law, which was formerly the royal system influenced by the Hindu tradition of Buddhism concepts.

They are studying the role of scholars who are responsible for spreading Salafi / cottage education in Johor Riau. Each related scholar has a distinctive role in developing the Islamic education of Salafi in Johor Riau especially covering the archipelago. The study was conductedabout the development of Salafi Islamic education in the Riau area that found that among the factors of the expansion of the Islamic education of the Salafi / cottage is the royal institution it self which has a close relationship with the ulama. Governments often seek advice from clerical groups to solve the problems they face.

This study is also conducted to identify more prominent figures and ulama who play a role in developing Islamic education of Salafi / cottages in Johor and the Riau Archipelago. Where they have their different ways of thinking to develop the Islamic education of the Salafi / cottage in the archipelago, the scholars and figures also post their books relating to Islamic education that will be listed in this study.

The purpose of this study is to create a level of understanding of how the history of the development and dissemination of Islamic education of Salafi or Islamic studies in the area of Johor Riau and especially the archipelago itself. Also, to identify the characters and ulama who play a role in the spread of Islamic education of Salafi / Pondok Johor Riau.

The scope of this study covers only the Islamic government in Johor Riau. Factors and also the effects on the Islamic education of the Salafi / cottage in the district of Johor Riau. The scope of the study focuses on the Johor Islamic government of Riau because most of them understand how the early arrival of Islamic education in the Riau and the archipelago in the colonial era. Therefore, the spread of Islam took place at that time. The arrival of Islam in Johor Riau has transformed the royal system of that era which emphasized Islamic law which 
was formerly the royal system influenced by the Hindu tradition of Buddhism that conceptualized the gods. This scope also focuses on the role of the characters and the ulama who are responsible for developing the Islamic education of Salafi / cottage in Johor and Riau especially in the archipelago and the books he has used.

\section{Result and discussion}

Islam has grown and developed in Malaya for a long time. The arrival of Islam has brought renewal to the life of a different Malay society with the formation of a new Islamic-based civilization. The influence of Islam not only succeeds in changing beliefs but also sociocultural Malay society in terms of governance, education, and culture. The Johor Government Religious School was created by order of His Majesty the Sultan of Johor, Almarhum Sultan Abu Bakar to provide religious education to Muslim children in Johor by using the Malay language free of charge to ensure that Islamic children in Johor receive regular religious education, perfect and controlled by the government.

The arrival of Islam to the archipelago was forced to confront the rival Hindu religion that has been established for the 13th century. However, all aspects of Islamic teachings have the advantage that Islam is easily accepted by the people of the archipelago. Symbolic Islam covers all aspects of mankind life. One of the benefits of Islam is easy to understand, not contrary to reason, always rational and well-suited to all people in all ages and places. For example, in the social aspect, Islam teaches that all humans are equal and the noblest human being in the sight of Allah is the most cautious. Also, Islam provides social security and justice, emphasizing the universal brotherhood of Islam, mutual assistance, respect, unity, etc.

Initially, Islam was brought by Arab traders to India,and Islamic India was spread to Malaya in the 15 th century. Since then and the Malays have been converted to Islam. The Malays have fought in many wars against the colonial powers, the Portuguese and the Dutch to protect their homeland as well as defend the religion of Islam. While the colonial powers besides wanting to strengthen their trade position, their main ideals were to spread Christianity among the Malays.

The development of Islam in Johor became stronger after the fall of Melaka on the Portuguese on 15 August 1511. After Sultan Mahmud Shah and his son Sultan Ahmad Shah died in battle against Alfonso d'Albuquerqe, his son and son escaped to Bertam, then to the Muar River and then retreated to Pagoh. After being attacked in Pagoh, Sultan Mahmud retreated to Pahang. After moving to several places, Sultan Mahmud finally founded in Bentan since 1521-1526M. Because Bentan was attacked again on October 23, 1526, Sultan Mahmud retreated to Kampar,and in 1528M, he died and was termed Kampar [7][8].

Sultan Mahmud's position was replaced by Sultan Muda, the son of Sultan Mahmud and Tun Fatimah. Sultan Muda who inherited the throne used the title of Sultan Alauddin Riayat Shah II. After taking over the throne, Sultan Alauddin retreated to Pahang, and eventually returned to Johor. Later, Sultan Alauddin built a government center in Sungai Johor near Sayong 25. In conclusion, Johor had accepted the arrival of Islam earlier than the setting up of the Malacca Malay government. However, the development of Islam in Johor is growing rapidly only when Johor is under the Malay kingdom of Malacca. Islam is growing in Johor after the Johor Malay government was founded in 1528M. Islam is reinforced through various methods and means taken through its initial reference from the Malacca Malay government. 


\subsection{Theory of Islamic Arrival}

\subsubsection{Theory from India}

Discovered by Snouck Hurgronje: "As if some Indians embraced Islam, the Muslims of India took the traffic and emigration in the archipelago and those that incorporated Islam into the archipelago." Then this opinion became popular,and some orientalists agreed, RO Winstedt, B. Harrison and others. Reason to establish this theory: The earliest tombstones found in Malay have been imported from Kambay (Kembayat) Gujerat [9][10].

The important role played by Gujerat traders in the Malay Archipelago and their impact on the spread of Islam. The Malay Literature tradition is more like the Islamic Indian tradition. Notes Marco Polo and Ibn Battuta who visited Alam Melayu around the 13th and 14th centuries. Found the tomb of Sultan Malik al-Salleh, the Pasai ruler mentioned in the Malay History and Hikayat of the Pasai Kings as the Government of I in the Malay Archipelago. The strength of the theory of Islam spread only around the 13th century AD. Theoretical weakness: Recent studies - the relationship between the Malay and Arab lands before the birth of Islam again. It is incorrect to say that tombstone found to resemble India, so Islam from India.

Are Not only Indian merchants trading in the Malay World but also from other places like China. The Arab traders who go to Canton also go to the Malay World at least to get some supplies or wait for the right wind to continue their cruise, and this is the time they used to trade. The literary tradition began to flourish long after the old Islam stepped on and expanded in India.

\subsubsection{Theory from China}

Prof.S.Q. Fatimi - the massive displacement of Muslims from Canton 876 (or 878) as a result of the rebellion that took place and the deaths of up to 100,000-150,000 Muslims made them go to the Malay World, among them according to S.Naquib to Kedah and Palembang. Also, to Champa, Brunei, east coast of Tanah Melayu (Patani, Kelantan, Terengganu,and Pahang) and East Java. Evidence from the tombstone of Sheikh Abdul Qadir in Langgar, Kedah, a stone inscribed with Phan-rang in Cambodia, Pahang's gravestone and a stone inscribed Terengganu 1303M. This Chinese influence is evidenced in the form of mosques in Malacca and Java such as Pagoda. The evidence presented is quite convincing but does not mean that Islam was only introduced at that time in the Malay world because there has been an Islamic placement at the beginning of the date, especially in the north of Sumatra [11].

\subsubsection{Theory of the Arab Land}

This theory has a lot of support: Hamka - there is evidence that the Arabs had sailed to Indonesia before the Prophet Muhammad's birth to buy spices and lime which only existed in Sumatra. Map/location of Alam Melayu has long been in the mind of the Arab.7M - Islam has reached Sumatra when Muawiyah bin Abi Sofyan sends a messenger to King Sriwijaya. Similarly, Umar bin Abd Azis has been promoting da'wah and business in the Malay World.

The reign of Caliph Sulaiman bin Malik - sent 35 fleets to the Sabak estuary in Jambi. This fleet is in the call off from Ceylon to Palembang 717M before to China. Arab traders had traded in the Malay World before Islam entered. This is because they have embraced Islam, then bermulalah Islam entry in the Malay. Most of the merchants from Yemen, Hadramaut,and Oman. Yemenian Islamicization of Ali bin Abi Talib's endeavor has 
implications for the conversion of Malay Nature as they spread Islam when they stopped at Alam Melayu.

Proof of the record of the history of the rulership of the kings in the Malay World was carried out by preachers from the Middle East. For example, the Emperor Drebar II who ruled Kedah in 1136M had embraced Islam from S. Abdullah bin S. Ahmad from Yemen by wearing the new name Sultan Muzafar Shah. Parameswara also converted to Islam from Shaykh Abdul Azis from Jeddah and renamed Sultan Muhammad Syah [12].

Islam has arrived since the first Hijrah (7th century AD) forming a Muslim village in northern Sumatra known as Ta-Shih. Arab influence in the Malay language is like the Book, Letter, Paper, and so on. Similarly, with the name of the Malays who have the power. From the above three theories, it can be concluded that Islam has come to Malaya since the 7th century. But it has been growing rapidly since the 11th-15th centuries since the establishment of the Islamic Kingdom in Malay land which has an important role in spreading Islam throughout the Malay world.

Islam has arrived since the first Hijrah (7th century AD) forming a Muslim village in northern Sumatra known as Ta-Shih. Arab influence in the Malay language is like the Book, Letter, Paper, and so on. Similarly, with the name of the Malays who have the power. From the above three theories, it can be concluded that Islam has come to Malaya since the 7 th century. But it has been growing rapidly since the 11th-15th centuries since the establishment of the Islamic Kingdom in Malay land which has an important role in spreading Islam throughout the Malay world.

\subsection{A Characterist and Ulama Developing Islamic Education Salafi / Pondok in Johor Riau}

\subsubsection{Habib Syed Hassan Al-Attas}

His full name is Syed Hassan bin Ahmad bin Zain Al-Attas. His Nasab is further up to the Messenger of Allah. He is a scholar of his time as well as his grandfather Habib Zain. His family's history of history began in the early 18th century when his grandfather migrated to Malaya. His grandfather then resides in Pahang state and is well-favored with his Royal family. He has made a lot of goodwill to the people and the people there. In 1832, Habib Hassan was born in Kampung Maulana in a house near the Tun Ali Palace (Pahang) [12].

During his lifetime, he was known as a scholar, preacher,and businessman who has sown a lot of services. There he founded the first Madrasah Al-Attas in Pekan Pekan. After his migration and residing in Johor, he set up another madrasah which was also named Madrasah Al-Attas. He is not only good with the community but has always been good with the Malay Rulers whether in the state of Pahang or Johor. In Johor, he was good friends with the Sultan of Johor, Sultan Abu Bakar until he was invited by his residence in Johor. In Johor, he lived in Kampung Habib Hassan (now known as Kampung Wadi Hassan).

He has set up two important institutions to ensure the legacy of organized Islamic education can be inherited in the land of Johor Darul Takzim. A low-level Islamic madrasah was established in 1913 at Bukit Timbalan and another middle class, Kuliah Al-Attas in 1932. In the same year, he was appointed the head of a group of Southeast Asian scholars attending the World Islamic Conference in Egypt. His multi-faceted talent, he has held several official posts in the government including Johor Police Commissioner (1913), Johor Bahru Town Board Member (1916), Kluang District Officer. 


\subsubsection{Syed Syeikh bin Ahmad Al-Hadi}

Syed Sheikh bin Ahmad al-Hadi is the son of Kampung Hulu, Melaka. He received basic Arabic language education, religion, reading and writing at his own home. In 1874, he and his family moved to Penyengat Island, Riau at the request of the Riau government with a very close family relationship with the upper classes in Melaka, including the Syed. His familiarity with the Riau royal family led to the call of 'Engku Anum' to replace his real name. After completing his studies in Riau, Syed Sheikh was sent to a cottage in Kuala Terengganu to pursue the science of religion and Arabic. At that time, the study of an individual was considered inadequate without learning at the cottage.

The cottage institution practices the method of learning rationally. This tradition caused Syed Sheikh not to be interested in pursuing his studies. Syed Sheikh is very well-known as one who is not easy to accept the teachings that are contrary to their own intellect and principles. The weakness of the system and the cottage institutions made him determined to return to Penyengat Island.

Upon returning to the Riau Archipelago, he studied Malay language and literature and religious knowledge from Raja Ali Kelana who also took him to the Arab states to expand his knowledge and experience. Syed Sheikh also had the opportunity to learn religion, Arabic,and Malay from the scholars who always visited the Sting. Also, various Malay-Arabic texts, books, magazines and newspapers contained in khutub khana in Penyengat Island are used as references to enable them to study the knowledge of fiqh, tafsir, tasawuf, philosophy, and the Qur'an. Syed Sheikh has a great influence in the Riau Palace,and he has been entrusted with accompanying the Royal Prince of Riau to Egypt, Mecca,and Beirut to pursue their religious studies there. This opportunity is used to enhance their understanding of religion and Arabic. He has the opportunity to learn from some famous scholars from the Malay world in Mecca such as Syed Abdullah al-Zawawi and Sheikh Wan Ahmad al-Fatani. The task and study of Syed Sheikh in Egypt ended when he decided to marry and settled on Penyengat Island in 1891.

After marriage, Syed Sheikh still has the opportunity to visit Mecca and Egypt for several times. Syed Sheikh's visit to Egypt has exposed him to the idea and movement of the reform leader Syeikh Muhammad Abduh he met for the first time in 1895 while accompanying Sheikh Ahmad al-Fatani and Raja Ali Kelana to Turkey. Syed Syeikh often sends letters with Rashid Reda, Muhammad Abduh's successor and the contents of his letter focus on al-Manar Magazine containing renewal ideas. The influence of Abduh's thoughts on Syed Sheikh was exposed through the reproduction of Abduh's writing in Syed Sheikh's magazines, Al-Iman and Al-Ikhwan.

Syed Sheikh performed the task of composing important articles while the author's job was overshadowed by Sheikh Muhammad Tahir due to his busy business managing a brick company in Batam (Batam Brickworks Company) owned by Raja Ali Kelana. Although he managed to attract readers outside Malaya. Due to the ongoing financial difficulty, the publication of al-Imam ends at the end of 1908. In early 1908 Syed Sheikh founded Madrasah Al-Iqbal Al-Islamiyyah in Singapore. His efforts reflect his concern for the spread of knowledge and the role of education in developing the Malays in particular, and Muslims in general. This madrasah applies a modern religious education system by combining her work with secularism. 


\subsubsection{Sheikh Tahir Jalaluddin}

Sheikh Tahir Jalaluddin was born on 7 November 1869 in Ampek Angkek, Bukit Tinggi, West Sumatra. He was born of Minangkabau Malay descent. His real name is Muhammad Tahir bin Shaykh Muhammad. His father was a Minangkabau Malay,and by that cause, among the Minangkabau people, Sheikh Muhammad is more famous by the name of Tuanku Muhammad or Tuanku Cangking it is the child to Tuanku Ahmad Jalaluddin. Since childhood, Sheikh Muhammad Tahir has become an orphan. She has been kept by the family next to her mother until she is 12 years old.

Like other children, Muhammad Tahir was given the opportunity to learn. He sailed to Makkah after his 12-year-old to study religion. While staying in Mecca, he had lived with his cousin Shaykh Ahmad Khatib who was then the leader of the Imam Syafie School at the Masjid al-Haram. Within 12 years Muhammad Tahir settled in Mecca, he had the opportunity to study the religious sciences profoundly. In 1893, he sailed to Egypt to pursue his studies at Al-Azhar University in astronomy. He succeeded in setting himself up as one of the most successful astronomers when he returned home. His extraordinary domination in astronomy led him to be known as Sheikh Tahir Jalaluddin al-Falaki. In addition to the field of astronomy, its ability in other fields of religion is also unmatched.

This may be a result of his efforts and diligence during his demands in Mecca as well as thanks to the divine gift that he has. His main teacher during Mecca was Shaykh Ahmad Khatib. Shaykh Ahmad Khatib's keenness is undoubtedly true. In addition to being a priest for Syafie sect followers in the Masjid al-Haram, he also became mufti to the followers of the Syafie sect in giving all the fatwa when there was any question from the followers of his school at that time.

The opportunity Sheikh Muhammad Tahir learns and lives with Sheikh Ahmad Khatib has greatly influenced him in the field of religion. Many of his teachers have influenced his soul. After spending two years teaching in Mecca, he returned home in 1899. Here he started his work in spreading the Islamic reforms he had received in Egypt before,Various duties and positions had been carried by him since returning to his homeland. Despite opposition from traditional clerics, he has never felt desperate or disappointed in his struggle.

Sheikh Tahir is a firm believer in matters pertaining to religion. This assertion is justified in his opinion because the reforms he organized are not intended to change religion to something new, but to correct the teachings of Islam that have been misunderstood. When he was in Muar, from 1924-1929, he had taught at Haji Taib School, Parit Jamil, Muar (formerly Madrasah Haji Taib). At that time the school had only 40 students in high school and 18 in the lower part. However, his students came from various places and states including Perlis. At teaching time, he always wears black cloak and tarbus. He also uses rattan which is specially prepared for his mischievous puppets. The rattan is stored in its robe and only removed when the situation is urgent.

Once upon a time, his naughty students were shattered and sometimes dirty with the purpose of teaching them. This is obvious because when teaching on the next day, he seems calm as usual, as if there were no events that occurred the previous day. This is a trait possessed by Shaykh Tahir who does not like to retaliate. Because of this, though most of his pupils are afraid of learning, they still love him. They will not escape from school because they know the anger of his teacher is not prolonged. Sheikh Tahir is also the right one by appointment. He is very much in agreement whether in terms of time, place or so. Her relationship with the local community is also very good. He never stops the youth playing football or the like either wearing long pants or short pants. This made the locals in Muar very respectful 
His personality has also placed him in the most respected place among the local people. He is also very careful in all matters especially in terms of eating and drinking. Sheikh Tahir is also a lover of science and likes to study books. He provided a special place for a reading room at his home. The room was well-screened so that mosquitoes could not get in. And so he focused his attention on the children while studying the lesson. He is willing to wait for his son Hamdan (Tan Sri Hamdan) to read the lesson by using only kerosene lamps. If possible, he wants his children to be great scholars.

\subsubsection{Ja'afar Mr. Abu Bakar Lingga}

The Treasurer of the Riau-Lingga Kingdom of Khazanah Name of Haji Ja'afar bin Encik Abu Bakar Lingga. He was educated in Mecca last time with the famous Nusantara ulama such as Tok Kenali. He received special education on political administration and personality with the Riau-Lingga Royal Family although he was not among the royal family, he was trusted by the sultan in the affairs of the Riau-Lingga government's important tasks [13].

$\mathrm{He}$ is the eldest and important figure of the Riau-Lingga Kingdom from Pulau Penyengat to Singkep Island and Lingga Island, and finally, the author obtained a document of Haji Ja'afar bin Encik Abu Bakar Lingga which is no less important than ulama and other Nusantara figures. In the document there are at least three things to place the scholar as the archipelago of the archipelago, who was once the Secretary of the Rusydiyah Club, was once the administrator of the Kingdom of the Riau-Lingga Khazanah Kingdom, who once served as an administrator to the Sultan and Terengganu government.Haji Ja ' afar bin Encik Abu Bakar received his last education in Mecca, as well as the famous Nusantara ulama such as Tok Kenali, Mufti Haji Abdullah Fahim, Kiyai Haji Hasyim Asy'ari, and others. Although Haji Ja'afar does not include the descendants of the Riau-Lingga Royal Family, because of the intelligence he has received special education about administrative and political affairs together with Riau-Lingga Royal Relatives at Istana Pulau Penyengat. Furthermore, the important tasks of the Riau-Lingga kingdom were given a lot of trust by the sultan and the Young Ruler to him. Until this article is written, the author does not know any other character who is not a royalty role in the Kingdom of Riau-Lingga such as Haji Ja'afar.

In his important note is his work in Faraid's Law, briefly addressed by Abu Hassan Sham. The book was settled in Kampung Baru, Daik, Lingga at 11 Safar $1334 \mathrm{H}$ assisted by his best friend,Haji Abdul Hamid ibn Isa Linga. Its contents are a summary of the ways of dividing the inheritance summarized from the book of Ghayatut Taqrib by Syeikh Daud bin Abdullah alFathani and Al-Manhajul Masyru 'by Sheikh Ahmad Khathib bin Abdul Lathif alMinankabawi. Printed by Mathba'ah Al-Ahmadiah, 101 Sultan Road, Singapore.

Another important note is that he was in Terengganu and worked as the Sultan of Terengganu Secretary. Notes start 1 Muharam $1337 \mathrm{H}$ until 1 Rabiulawal $1341 \mathrm{H}$. In this note we can know the very close relationship between Haji Ja'afar with the Sultan of Terengganu and Terengganu castles other than his sultan. In addition, there are so many important things that happen within that time period, for example among them the death of King Haji Muhammad Sa'id bin Raja Haji Muhammad Tahir ulama and the famous author of Riau. Haji Ja'afar Lingga wrote, "11 Safar $1338 \mathrm{H}$, Tuesday night, $9 \mathrm{pm}$, to the port of Singapore. 


\section{Conclusion}

The development of Islam into the Malay world has fueled the development and development of learning and knowledge among Malays. Islam has introduced various knowledge such as philosophy, astronomy, mathematics, law, tasawwuf, jurisprudence, etc. The educational and learning efforts of all these sciences are presented through the intermediate language of the Malay language. The result of the Malay language is not only growing but being a language capable of discussing various disciplines that are recorded in the yellow Malay texts. This scientific revolution revolutionized the tradition of science to produce thousands of educational institutions. Students from this educational institution are the ulama who play an important role in the life of the Malay community. Because the birth of this tradition of science began the era of renewal for Malays.

\section{References}

[1] A. Z. bin Ghazali and Z. A. Borhan, Johor Dulu dan Sekarang. Malaysia: Persatuan Muzium Malaysia, 1994.

[2] A. B. A. Hamid and M. I. Zamzam, Johor Mengabadikan Baktimu. Johor Bahru: Yayasan Warisan Johor, 2005.

[3] A. B. A. Hamid, M. I. Zamzam, and I. Kamdi, Johor Mengenang Sumbangsihmu. Johor Bahru: Yayasan Warisan, 2006.

[4] A. Ikhwan, "Perguruan Tinggi Islam dan Integrasi Keilmuan Islam: Sebuah Realitas Menghadapi Tantangan Masa Depan," At-Tajdid J. Ilmu Tarb., vol. 5, no. 2, p. 160, 2016.

[5] A. Ikhwan, "Kajian Sosio-Historis Pendidikan Islam Indonesia Era Reformasi," Edukasi J. Pendidik. Islam, vol. 5, no. 1, p. 17, 2017.

[6] A. Ikhwan, "Development Of Quality Management Islamic Education In Islamic Boarding School (Case Study Madrasah Aliyah Ash Sholihin)," Al-Hayat J. Islam. Educ., vol. 1, no. 1, p. 117, 2017.

[7] A. R. H. Abdullah, Gerakan Anti Penjajah di Malaysia 1511-1950; Pengaruh Agama Tarikat. Kuala Lumpur: Penerbitan Kinta Sdn. Bhd, 1994.

[8] M. I. Zamzam, Jurnal Warisan Johor, jilid IV. Johor Bahru: Yayasan Warisan Johor, 2000 .

[9] M. I. Zamzam, "Memelihara Warisan Budaya Jilid II,” J. Waris. Johor, 1998.

[10] M. A. Al-Banjari, Sabil Al-Muhtadin li Al-Tafaqquh fi amrAl-Din. Jakarta: Perpustakaan Nasional, 2001.

[11] M. Y. al-Maqassari, Tuhfat al-Abrar, MS. MS. Jakarta: Perpustakaan Nasiona, 2005.

[12] N. A.-D. Al-Raniri, Bustan Al-Salathin, MS. Leiden University, Cod, Or. A41; Jakarta: Perpustakaan Nasional.

[13] Hawash Abdullah, Perkembangan Ilmu Tasawwuf dan Tokoh-Tokohnya di Nusantara. Surabaya: Al-ikhlas, 1980. 